\title{
THE PAST QUARTER CENTURY OF JAPANESE SOCIETY OF PHYSICAL EDUCATION
}

\author{
Tetsuo MESHIZUKA \\ (Tokyo Metropolitan University)
}

\begin{abstract}
Membership
A quarter century span since its establishment has elapsed for the society which enjoys approximately 3,000 members today from such varied areas as schools, colleges, universities, administrative boards, sport medicine and clinics, amongst the membership of colleges and univesities are greatest of all.
\end{abstract}

\section{Activities}

The main professional activities of the society are (a) annual national convention, (b) publication of "Research Journal of Physical Education", editing of "Journal of Physical Education" sponsored by a publisher, and "List of Members" every two years, (c) advisory assistance for the selection of the research projects proposed by the members for the National Research Grants, (d) affiliation to ICHPER, ICSPE, FIEP, APEA (Asian P.E. Association) and Japanese Union of Sport Sciences. One of the highlights during the past 25 years was "the International Congress of Sport Science" (ICSS) held in 1964 in Tokyo in concurrence with Tokyo Olympics which attracted a great many of professional people not only from physical education, health education, recreation, but also from sport medicine, sport coaches and trainers. This congress may be historically conoted because of its spirit of establishment and organization, i. e, people both in physical education and sport medicine cooperated closely under the Japanese Union of Sport Sciences consisting of Japanese Society of Physical Education and Japanese Society of Sport Medicine in order to successfully carry on the congress. This entailed the congresses similar to ICSS since 1964, as seen in Munich in 1972.

\section{ICSS and ICSPFT, ACSPFT and ICPFT}

Two special comittees of ICSS : (1) International Committee for Standardization of Physical Fitness Tests, and (2) Doping were prepared and the former has been later developed into ICSPFT under the chairmanship of Professor L. A. Larson (U. S. A.) with the executive office in Japan (Professor T. Ishiko)* until the meeting in Javayskla, Finland in 1973. This

* Location: ICSPFT Office, Faculty of Physical Educatoin, Juntendo University, Fujisaki, Narashino, Chiba, Japan 
committee came to agree to draft the standardized tests in four areas related to physical fitness; (1) Medical examination, (2) Physiological measurements, (3) Physique and body composition, (4) Per formance test. After the finalization of these tests, the committee was re-named to be ICPFR (International Committee of Physical Fitness Reasearch) which implies to carry on the research and survey internationally, intergeographically or interracially with the tests established as their main instruments.

As one of the local committees for the above, the first such professional organization was ACSPFT (Asian Committee for Standardization of Physical Fitness Tests) with late Professor M. Ikai as chairman and its office located at Professor T. Meshizuka's laboratory*. This committee made efforts to apply these tests prepared by ICSPFT upon a number of Asian populations to report the results. It will remain as it is entitled today despite the re-naming of the parental committee.

\section{APEA (Asian Physical Education Association)}

The Asian Congress of Physical Education (ACPE) was organized officially in 1962 in Tokyo in the occasion of Asian Games. After Tokyo congress, two congresses in succession were organized by enormous sympathy and efforts on the part of Thai colleagues in 1966 and 1970 respectively, and it seems rather incapable to have the meeting in Teheran this year.

\section{International Seminar related to 24th Convention}

Five scholars were invited by the organizing committee of the 24th convention in $\mathrm{Na}$ goya, 1973; Åstrand, P. O. (Sweden) in Physiology, Willie, A. (Australia) in Administration, Neugent, T. (U.S. A.) in Rehabilitation, Adrian, M. (U. S. A.), in Kinesiology, and Miller, B.W. (U.S.A.) in comparative physical education.

\section{Publications}

The Research Journal of Physical Education numbers today 17 volumes and 5-6 issues a year, while the Journal of Physical Education co-edited and published monthly by a publisher now reaches to 24 volumes. The former accepts, the subsidary fund of the Scientific Research Grants through Ministry of Education and issues at least one number for the oversea subscribers in English as the present issue actually is the one. Other issues also can include English or Japanese papers dependent on the preference of the authors. Not many articles so far were contributed by over-sea special members and the society always expects to have the articles sent by those over-sea members and research workers who would willingly fulfil the fees

* ACSPFT Office, Physical-fitness Laboratory, Tokyo Metropolitan University, 1-1-1, Yagumo, Meguroku, Tokyo, Code 152. 
which approximates to $10 \mathrm{U}$. S. dollars equivalent to 2,700 Japanese yen.

The latter publication has been technically and economically produced by a publisher in Tokyo and the society co-edits the periodical so as to distribute among the members as well as to the general public for the fixed fees by the publisher. This periodical conveys various contemporary news relative to the society, national administration, interational trends and meetings, school physical education, recreation in order to function partially as the organ periodical for the society.

The society also encourages the sponsoring body of the annual convention to edit and distribute the special summary volume of the reports to be presented in various divisions for the price settled by the committee. This volume, however, used to be in the series of the Research Journal until 1969.

\section{Research Divisions and Classification of Convention Reports}

Ten research divisions respectively initiated by the autonomous professional actions of the members gradually became the classification standards for the convention reports. The special research divisions follows;

Aspects and title

1. Sociological Studies

2. Exercise Physiology

3. Measurement and Evaluation

4. Administration

5. Methods

6. Philosophy and Principles

7. History

8. Psychology

9. Kinesiology

10. Growth and Development

11. Other
Foundation

$\begin{array}{ll}1961 & 28 \\ 1961 & 58 \\ 1964 & 42 \\ 1964 & 13 \\ 1968 & 81 \\ 1962 & 15 \\ 1961 & 28 \\ 1950 & 34 \\ 1957 & 40 \\ 1965 & 29 \\ & 31\end{array}$

Some movements for the initiation of physical therapy and rehabilitation appear to be existing further and any of new division is to be examined by the standing executive board and accepted by the general assembly held annually during the convention. The research budget for these divisions today counts $¥ 20,000$ ( $\$ 70.00$ U.S.)each and these divisions collect fees also for their own activities.

The degree of affiliation to these divisions of the total membership is about 50 per cent and the rest of the members ought to be affiliated to 28 local societies except the special members who directly belong to the society due to their geographical and international addresses scattered. 
Any of the interested colleagues out-side Japan are always invited to become the member of our society and dedicates their professional contributions to the society just by proposing the membership with fees paid (\$10.00 U.S.) which also qualifies to subscribe all the publications.

\section{Assigned Research Projects}

In addition to the research papers classified according to the special research divisions, the society in these years decides the research problems to be attacked by both members in general and the members nominated by the society. The followings are the titles in the past two conventions:

1972: (1) Amateurism

(2) Public nuisance and exercises

(3) Women physical education

(4) Community sports and physical education

1973: (1) Psycho-somatic effects of exercise experiences during infant and juvenile periods

(2) Women's physical education

(3) Physical fitness diagnosis of the middle-aged

(4) Unbalanced physique and physical-fitness of youth and exercise-prescription

(5) Problems of community physical eduaction - especially under the urbanization trends-

As briefed in this issue under the special research division, several symposia are managed recently in combination of two or three divisions. These integrated symposia in 1973 were:

(1) Learning process of exercise technics.

(2) Optimum amount of exercise for elementary and high school physical education

(3) Relation between motor ability and mental development of infant and juvenile periods

(4) Promotion of sport clubs in community

(5) National tasks of physical education-welfare and physical education-

(6) Today's sport policies -along the popularization of sports-

\section{International and inter-disciplinary status}

For the first time in its history, the society succeeded in sending a representative to Japanese Council of Sciences since 1969. It has enough membership capable of capacity to electing at least two representatives provided that all the members would have registered for the ballot to obtain the right to vote. Only one-sixth of the membership so far has been registered.

$\begin{array}{lll}\text { Members of Council } & \text { Matsui, M. (ex-president) } & 1969 \sim 1971 \\ & \text { Kato, K. (ex-president) } & 1972 \sim 1974\end{array}$


The society also contributes to ICHPER, ICSPE, ICPFT, ACSPFT and many other international organizations and cooperate closely with FIMS, ACFIMS, pedagogy and psychology societies and Sport-Science Research Institute of JASA.* Among them, today it sends vicepresident for ICHPER (Ebashi, S.) and ICSPE (Meshizuka, T.).

This year of 1974 happens to be the 25th anniversary of the society and some festivities seem to be arranged during the 25 th convention in Tokyo. Many participants from abroad are expected to attend the convention during October 5,6 and 7th, in Tokyo, 1974.

* Japan Amateur Sport Association, 25, Jinnan, Shibuya-ku, Tokyo, Japan 